\title{
Japanese Students' Attitudes Towards the Use of Facebook in the EFL Classroom
}

\section{Gilbert Dizon}

Himeji Dokkyo University

Facebook is the most widely used social networking site in the world. However, little is known of the views that Japanese students have towards its use to enhance language learning. This paper reports on a survey of students in Japan to determine their perceptions of the use of Facebook in four EFL courses. The participants were 41 students who were a part of the Faculty of Foreign Studies at a university in Japan. Students were divided into separate Facebook groups according to their class and were required to participate in weekly discussions through the site. The results revealed that the survey respondents had moderately favorable views of using Facebook to learn English. In particular, the site's ease of use, convenience, and low-stress environment were seen as distinct advantages. These findings illustrate that Japanese students perceive Facebook as a beneficial tool for language learning.

Facebookは世界中で最も広く利用されているSNS (ソーシャルネットワ ーキングサービス) である。しかしFacebookの言語学習への利用につい て、日本の学習者がどんな認識を持っているかはほとんど知られていな い。本論では4つのEFLクラスでの、Facebook利用に関する日本人英語学 習者の認識調査を報告する。対象者は大学の外国語学部に属する英語 学習者41名で、クラスごとに別のFacebookグループに分けられ、週に1度 Facebookを通じたディスカッションに参加した。その結果、英語学習の ためのFacebook利用に関して、学習者は概ね好意的な認識を持っている ことが示された。特に、サイトの使いやすさ、便利さ、ストレスの低い環境 といった要因が大きな利点として挙げられた。これらの結果から、EFL学 習者がFacebookを言語学習の有益なツールとして捉えていることが明ら かになった。

\section{$\mathbf{A}$} lthough numerous social networking sites have sprung up over the past decade, the most widely used one is Facebook. As of December 2014, the site had 890 million daily active users, with approximately $82 \%$ of them outside of the US and Canada (Facebook, 2015). Because of this, Blattner and Fiori (2009) state that language teachers "need to capitalize on the fact that Facebook is already an integral part of many students' e-routine" (p. 21). However, while online academic platforms such as Blackboard and Moodle have been used extensively at the university level, integration of Facebook has lagged behind despite its potential as a powerful learning tool.

Nonetheless, some believe that Web 2.0 technologies such as Facebook may not be appropriate or constructive in the context of formal language teaching and learning (Lohnes \& Kinzer, 2007; Waycott, Bennett, Kennedy, Dalgarno, \& Gray, 2010; Salaway, Caruso, \& Nelson, 2007). Moreover, though EFL students' views of Facebook have been studied in other regions (Shih, 2011; Bani-Hani, Al-Sobh, \& Abu-Melhim, 2014; Omar, Embi, \& Yunus, 2012; Suthiwartnarueput \& Wasanasomsithi, 2012), little is known about the attitudes of students in Japan regarding the use of Facebook to learn English. Given this gap in the literature, the primary aim of this study is to investigate the perceptions of Japanese EFL students concerning the use of Facebook in the classroom.

\section{Background}

Not only have recent studies shown that Facebook can support foreign language learning, but students seem to have positive views of its use. Shih (2011) examined the effect of incorporating Facebook in an English writing class at a university in Taiwan. The 23 students who participated in the study were divided into three groups based on their English proficiency level: high, medium, and low. Each group was then further divided into two separate Facebook groups or sites where the learners were responsible for posting their weekly assignments, evaluating the writing of their peers, and giving feedback and comments. The participants were given pre- and post-tests of their English writing to determine the impact that the Facebook assignments had on their writing development. The results showed that the learners were able to develop their English organization, grammar and structure, content, vocabulary, as well as spelling through the activities.

In addition to analyzing the students' writing, Shih (2011) also investigated their attitudes towards the use of Facebook in a blended learning environment through a 30-item questionnaire. Each item was based on a 5-point Likert scale, ranging from strongly agree to strongly disagree. He found that the students had moderately to highly positive views regarding the use of Facebook in the course. Moreover, the participants indicated that the blended learning approach could help improve the students' communication, trust, friendship, and 
interaction with one another as well as enhance their motivation.

A study by Bani-Hani, Al-Sobh, and Abu-Melhim (2014) also looked at students' perceptions of Facebook in an EFL classroom. The 42 female Jordanian university students in the study were added to a Facebook group by the researchers and were instructed to brainstorm, write an entry, and then give each other corrective and formative feedback. According to the results of the 10-item survey created by the researchers, the participants viewed Facebook as being beneficial to the development of their English writing skills. Nevertheless, nearly half of the students preferred a traditional task instead of writing via Facebook. This is significant because it reveals that some learners may not perceive social networking sites such as Facebook to be appropriate for formal teaching and learning activities.

Another study that incorporated Facebook in an EFL context is Omar et al.'s (2012) investigation of English learners' use of Facebook groups in taskbased activities. The 31 learners in the study were enrolled in an English language communication course at a university in Malaysia. Students were divided into seven groups, each based on a theme chosen by the learners and the instructor. After the conclusion of the task, the learners' participatory patterns were analyzed and their perceptions of Facebook were collected via an open-ended questionnaire. According to the results of their study, Omar et al. (2012) found that the students displayed a high-level of participation, with each student averaging 18 entries, three times the number that was required. Moreover, the authors discovered that 100 percent of the questionnaire respondents $(n=28)$ had favorable views towards the use of Facebook in an information-sharing task. Notably, many of the students also expressed that the site allowed them to "communicate more freely and comfortably with their group members, especially those who were shy and lacked confidence for face-to-face interaction" (p. 71). This is an important finding as it suggests that Facebook can help lower the affective filter (Krashen, 1982) of L2 learners.

Suthiwartnarueput and Wasanasomsithi (2012) also carried out a study examining the use of Facebook in the L2 classroom. A total of 83 first-year university EFL students in Thailand took part in the study, which examined the effects that Facebook had on the writing skills of the learners. Pre- and post-tests were administered to assess the students' English grammatical and writing competence. The authors concluded that Facebook did indeed enhance competence in both areas. Moreover, in order gain more insight into the learners' views of the site, semi-structured interviews were conducted with 13 of the participants. According to Suthiwartnarueput and Wasanasomsithi (2012), all of them had positive perceptions towards its use. In addition, many of the interviewees noted the convenience that Facebook offered in communicating with their teacher and peers.

In summary, Facebook has been shown to be an effective tool in enhancing language learning in the EFL classroom. In addition, students seem to enjoy learning English through the unique medium of Facebook because it lowers learner anxiety, provides more opportunities for interaction, improves students' interpersonal relationships, and fosters motivation. Thus, the author decided to utilize Facebook in his classes to take advantage of these potential benefits and explore Japanese EFL students' views of its use.

\section{Research Questions}

This study examined the following research questions:

1. Did the students have prior academic experience of learning English on Facebook?

2. To what extent did the students make use of the class Facebook page to learn English?

3. How did the students prefer to access the class Facebook page?

4. What are the attitudes of Japanese students towards the use of Facebook in the EFL classroom?

\section{Participants}

The participants in the study consisted of 41 firstsecond- and third- year students in the Faculty of Foreign Studies at a university in western Japan. All of the students were enrolled in one or more of the four English language classes taught by the researcher, which utilized Facebook during the second semester of the 2014-2015 academic year. Students' proficiency levels ranged from low to intermediate based on their TOEIC Bridge and TOEIC IP scores.

\section{Methodology Utilization of Facebook in the Courses}

Facebook was used as the medium for all written tasks and assignments in the four courses involved in the study. Students were divided into separate Facebook groups based on their class. Each group was closed, meaning that member posts were hidden from the public. Figure 1 below shows a screenshot from one of the class Facebook group pages. 


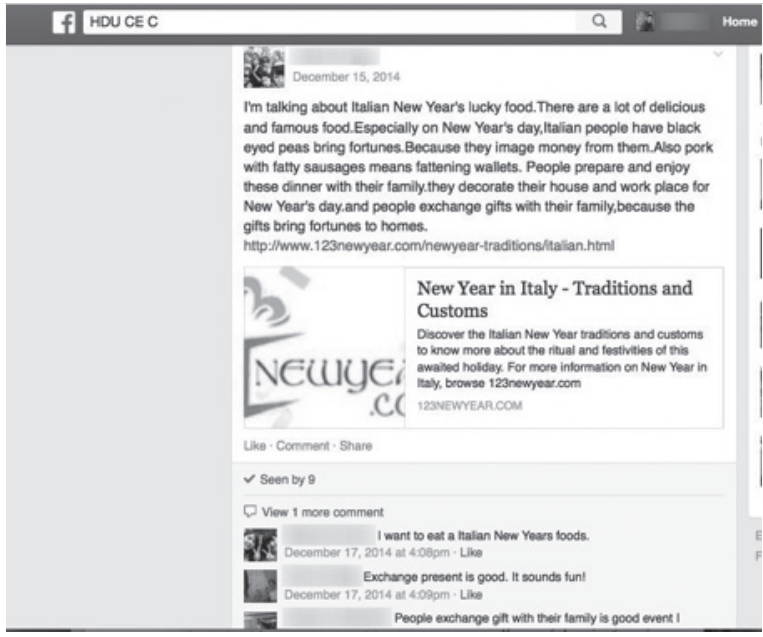

Figure 1. Class Facebook group page.

Students were required to write on a variety of topics in class and respond to other student entries either during or outside of class. They were also encouraged to share pictures, videos, and links in their posts. The researcher acted as a moderator and facilitated discussion through his own entries and comments. He also provided corrective and formative feedback on students' posts via the Facebook messenger or chat feature. However, this was not a significant part of the use of Facebook for this study as it was only given for major assignments.

\section{Research Instrument}

Data was collected via a 13-item questionnaire consisting of closed- and open-ended questions (see survey at <http://surveymonkey.com/r/XFB2DH6>). The survey was created by the researcher based on current literature on blended learning and Web 2.0 technologies and their use in $\mathrm{L} 2$ contexts. The survey was arranged into four parts. The first section contained three closed questions related to the students' experience and use of Facebook; namely, prior academic usage of the site, access preference (PC vs. mobile), and frequency of class page access. The second and third portions of the questionnaire included eight closed questions, which examined potential linguistic (four questions) and affective advantages (four questions) of Facebook. The final section consisted of two open-ended questions, which asked students to comment on what they liked and did not like about the use of Facebook in the EFL courses.

Completion of the questionnaire was voluntary. Students were informed of the intentions of the research and were ensured that all responses would remain anonymous. The survey was administered online via SurveyMonkey outside of class. In other words, class time was not used in order to collect data for the research in this study.

\section{Results and Discussion}

Out of the 45 students in the classes, 41 (91\%) participants responded to the questionnaire. Items one through eleven were evaluated using descriptive analysis. Responses to the open-ended questions were analyzed based on the emergent methodology approach in which data is coded and analyzed to determine meaningful themes (Suter, 2012).

Have you used Facebook to learn English in another class before this course?

In response to prior formal learning experience with Facebook, 15 (36\%) stated that they had some. While still a minority of the respondents, this number is somewhat surprising given that the social networking site has not been widely used in tertiary education (McCarthy, 2010). Language instructors may be resistant to using Facebook in the classroom yet as Blattner and Fiori (2009) note, "As educators it is essential to take advantage of such technological tools to enhance autonomous language education and abandon our pre-digital instinct and comfort zones" (p. 25).

\section{How often do you view the class Facebook page?}

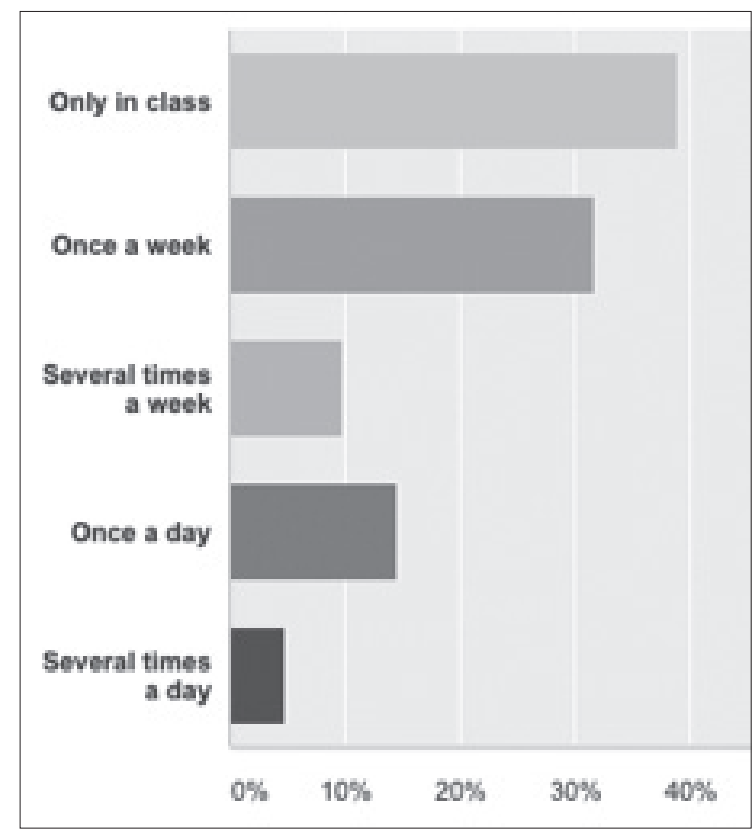

Figure 2. How often students state they use the Facebook page. 
Figure 2 shows how often students report using the Facebook page. Although Facebook may have offered more opportunities to use English, the majority of the students (71\%) accessed the class page once a week or only when required to during class. Therefore, it can be concluded that most of the learners did not take full advantage of the extra opportunities to use the target language outside of the classroom. With that said, eight of the respondents (19\%) frequently visited the page, viewing it at least once a day. This disparity illustrates the variability between learners when incorporating computer-assisted language learning (CALL), particularly in less-controlled environments such as the Internet (Fischer, 2012).

\section{How do you prefer to access the class Facebook page?}

Regarding question three, more than half of the respondents (56\%) preferred accessing the Facebook course pages via a mobile device as opposed to a PC. This preference for mobile technology represents the current shift from PC's to mobile devices (Walters, 2012). According to Jee (2011), mobile technology "affords second or foreign language learners and teachers ever greater opportunity to practice the target language" (p. 162) regardless of time and place. Thus, as the ownership rate of internet-enabled mobile devices continues to grow, so does the need for teachers to leverage their usage and utilize them to help foster language development.

\section{Linguistic and affective advantages of Facebook}

The eight items related to the linguistic and affective advantages of Facebook had mean scores ranging from 3.46 to 3.80 on a 5 -point Likert scale (1=strongly disagree, $2=$ disagree, $3=$ not sure, $4=$ agree, $5=$ strongly agree) with standard deviations between 1.01 and 1.23, indicating the students generally agreed with the statements (Table 1). Item eight, "I enjoy learning English through Facebook," received the highest level of agreement with a mean score of 3.80, suggesting that the students perceived writing on Facebook to be a fun and engaging activity. Equally important, items nine and eleven (Table 1), which were related to stress and comfort-level when writing on Facebook, received relatively high scores as well (3.63 and 3.68), signifying that the site helped support an open and comfortable setting for language learning. This echoes a statement made by Jee (2011) regarding one of the affective benefits of Facebook, "The friendly, fun environment of Facebook can help to reduce foreign language learner anxiety, especially in early stages of acquisition" (p.
168). Moreover, these findings correspond with the opinions held by the participants in Shih's (2011) study who viewed Facebook as an interesting and low-stress method to learn English.

Table 1. Results for Questions 4-11

\begin{tabular}{clcc}
\hline No. & \multicolumn{1}{c}{ Statement } & Mean & $S D$ \\
\hline 4 & $\begin{array}{l}\text { My use of English grammar is } \\
\text { better because of Facebook. }\end{array}$ & 3.56 & 1.01 \\
5 & $\begin{array}{l}\text { My use of English vocabulary } \\
\text { is better because of Facebook. }\end{array}$ & 3.59 & 1.06 \\
$6 \quad \begin{array}{l}\text { My English reading skills are } \\
\text { better because of Facebook. }\end{array}$ & 3.63 & 1.12 \\
$7 \quad \begin{array}{l}\text { I can express myself more } \\
\text { easily in English because of }\end{array}$ & 3.46 & 1.23 \\
$\quad \begin{array}{l}\text { Facebook. } \\
8\end{array}$ & $\begin{array}{l}\text { I enjoy learning English } \\
\text { through Facebook. }\end{array}$ \\
$9 \begin{array}{l}\text { I feel less stress writing in } \\
\text { English on Facebook than } \\
\text { pencil-and-paper writing. }\end{array}$ & 3.80 & 1.19 \\
$10 \begin{array}{l}\text { I am more motivated to write } \\
\text { in English on Facebook than } \\
\text { pencil-and-paper writing. }\end{array}$ & 3.56 & 1.17 \\
11 & $\begin{array}{l}\text { I am more comfortable } \\
\text { communicating with my } \\
\text { classmates and teacher on } \\
\text { Facebook than pencil-and-pa- } \\
\text { per writing. }\end{array}$ & 3.68 & 1.20 \\
\hline
\end{tabular}

\section{Written answers}

In response to the first open-ended question, "What do you like about using Facebook to learn English?" several students remarked about the ease of use and convenience of the site:

"It's easy and I can see it anywhere at any time."

"English on Facebook is really near to me so I can enjoy and use English through SNS easily. Moreover it is really practical English."

"Easy to writing and we can search on the Internet."

"It is good to write easily."

"I can easily comment."

In addition, a few students mentioned they enjoyed using the site because it was a modern way to study English: 
"It looks modern, and it is useful. I should print out my report in another class. Therefore, I think Facebook is better."

"It's interesting and modern!"

Concerning the second open-ended question, "What do you not like about using Facebook to learn English?" many students complained about the poor performance of the computers and the inability to respond to others quickly:

"PCs are very slow."

"I hate it when my PC is very slow."

"I cannot fast comment."

This sentiment may have contributed to more students preferring mobile devices to PC's when accessing the class Facebook page.

Also significant, one student stated that he or she did not use Facebook and as a result, would have preferred an alternate way to complete the writing tasks:

\section{"I don't Facebook so I prefer other something."}

This is a reminder that although social networking sites are very popular among young people, there may be a few students who either do not use them or dislike communicating with their teacher and peers over the Internet. Therefore, it is essential for instructors to help all learners understand the benefits that Facebook and other Web 2.0 technologies can offer them (Blattner \& Fiori, 2009).

To conclude, the participants in the study had moderately favorable attitudes towards the use of Facebook in the EFL classroom. According to the results of the questionnaire, the learners enjoyed using the site to learn English. Specifically, they liked the convenience of Facebook, which allowed them to easily comment and respond to others anytime and anywhere. However, the majority of the learners did not frequently visit the course Facebook pages outside of class, illustrating the fact that students may not take advantage of the opportunities given to them. Furthermore, several students stated that they had issues with the speed of the computers and Internet connection at the university. Thus, the availability and performance of computers or mobile devices, as well as a reliable Internet connection both inside and outside of class, need to be taken into account when incorporating Facebook into the classroom.

\section{Conclusion}

Facebook has the ability to transform language learning and extend communication outside of the confines of the classroom. The convenience it provides affords learners opportunities to communicate synchronously and asynchronously, while also decreasing the anxiety of students who may be too timid to use the L2 in a face-to-face setting. Hence, based on the findings of this study, the author supports using Facebook in the classroom to enhance foreign language learning. While skepticism and resistance to the incorporation of Web 2.0 tools will inevitably remain, social networking sites do and will continue to play an important role in many students' lives. Therefore, teachers must be aware of Facebook's potential to foster language development by affording learners additional opportunities to meaningfully interact in the L2 in a low-stress environment.

\section{References}

Bani-Hani, N. A., Al-Sobh, M. A., \& Abu-Melhim, A. R. H. (2014) Utilizing Facebook groups in teaching writing: Jordanian EFL students' perceptions and attitudes. International Journal of English Linguistics, 4(5), 27-34.

Blattner, G. \& Fiori, M. (2009). Facebook in the language classroom: Promises and possibilities. International Journal of Instructional Technology and Distance Learning, 6(1), 17-28, Retrieved from http://www.itdl.org/ journal/jan_09/article02.htm

Facebook. (2015). Company Info | Facebook Newsroom. Retrieved January 29, 2015, from http://newsroom. fb.com/company-info/

Fischer, R. (2012). Diversity in learner usage patterns. In G. Stockwell (Eds.), Computer-Assisted Language Learning: Diversity in Research and Practice (pp. 14-32). New York, NY: Cambridge University Press.

Jee, M. J. (2011). Web 2.0 technology meets mobile assisted language learning. The IALLT Journal, 41(1), 161-175.

Krashen, S. (1982). Principles \& Practice in Second Language Acquisition. New York, NY: Pergamon Press.

Lohnes, S. \& Kinzer, C. (2007). Questioning assumptions about students' expectations for technology in college classrooms. Innovate, 3(5), Retrieved from http://www. innovateonline.info/index.php?view=article\&id=431

McCarthy, J. (2010). Blended learning environments: Using social networking sites to enhance the first-year experience. Australasian Journal of Educational Technology, 26(6), 729-740. Retrieved from http://www.ascilite. org.au/ajet/ajet26/mccarthy.html

Omar, H., Embi, M. A., \& Yunus, M. M. (2012). ESL learners' interaction in an online discussion via Facebook. Asian Social Science, 8(11), 67-74. 
Salaway, G., Caruso, J. \& Nelson, M. (2007). The ECAR study of undergraduate students and information technology, 2007. Boulder, Colorado: EDUCAUSE Center for Applied Research. Retrieved from http://www. educause.edu/ECAR/TheECARStudyofUndergraduateStu/161967

Shih, R. C. (2011) Can Web 2.0 technology assist college students in learning English writing? Integrating Facebook and peer assessment with blending learning. Australasian Journal of Educational Technology, 27(5), 829-845. Retrieved from http://www.ascilite.org.au/ ajet/ajet27/shih.html

Suter, W. M. (2012). Introduction to educational research: A critical thinking approach ( $2^{\text {nd }}$ ed.). Thousand Oaks, Calif.: SAGE.

Walters, T. (2012). Understanding the "mobile shift": Obsession with the mobile channel obscures the shift to ubiquitous computing. Digital Clarity Group. Retrieved from http://digitalclaritygroup.com/wordpress/wp-content/ uploads/2012/12/DCG-Insight-Understanding-the-Mobile-Shift-Nov-2012.pdf

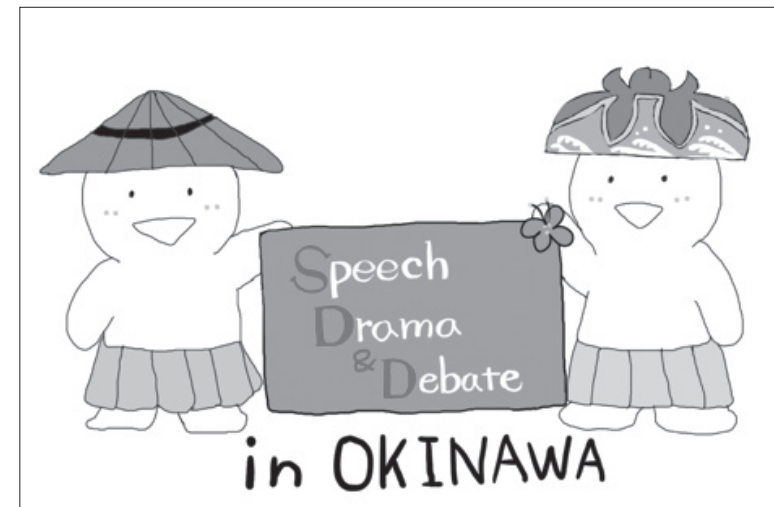

\section{A FULL 2-DAY CONFERENCE AND SPEECH CONTEST}

OCTOBER 31 - NOVEMBER 1, 2015 MEIO UNIVERSITY, NAGO, OKINAWA

\section{- SPONSORED BY -}

SPEECH, DRAMA, \& DEBATE SIG AND JALT OKINAWA CHAPTER

FOR MORE INFORMATION SEE https://sites.google.com/site/ sddsigevents/
Waycott, J., Bennett, S., Kennedy, G., Dalgarno, B. \& Gray, K. (2010). Digital divides? Student and staff perceptions of information and communication technologies. Computers \& Education, 54(4), 1202-1211. http://dx.doi. org/10.1016/j.compedu.2009.11.006

Gilbert Dizon is a lecturer at Himeji Dokkyo University, Japan. He holds a Master of Arts in Applied Linguistics from the University of Massachusetts Boston. His current research interests include computer-assisted language learning, mobile-assisted language learning, and L2 writing. He can be reached at < gilbert.dizon.jr@ gmail.com $>$.

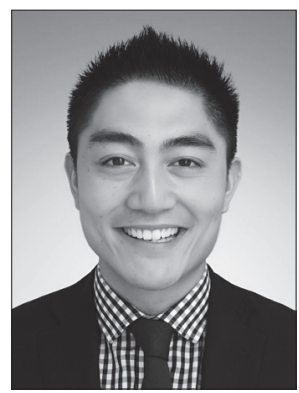

\section{号}

CREATING COMMUNITY LEARNING TOGETHER コミュニティの創造:共に学ぶ 学習者ディベロプメント研究部会

OTSUMA WOMEN'S UNIVERSITY SUNDAY DEC 13, 2015

\section{Sunday December 13 2015, Otsuma Women's University, Ichigaya, Tokyo}

Please come and join us for the second Creating Community: Learning Together conference. The conference provides opportunities for students and teachers to give poster presentations or digital displays, with many chances for conference attendees and presenters to listen, talk, reflect, and learn together.

\section{Call for Contributions:}

September15 - October18, 2015

For more details:

$$
\text { http://ld-sig.org/creating- }
$$

community-learning-together-2015/ 